\title{
IDENTIFIKASI PENCEMARAN LOGAM BERAT TEMBAGA (Cu), TIMBAL (Pb) DAN KADMIUM (Cd) AIR LAUT DI SEKITAR PELABUHAN TELUK BAYUR KOTA PADANG
}

\author{
Widya Anggraini, Dwi Puryanti*
}

Jurusan Fisika, FMIPA, Universitas Andalas, Limau Manis, Padang, 25163

*Korespondensi ke: dwipuryanti@yahoo.co.id

( Diterima:15 Juli 2019; Direvisi: 02 Agustus 2019; Diterbitkan: 01 September 2019)

\begin{abstract}
ABSTRAK
Telah dilakukan penelitian mengenai identifikasi pencemaran logam berat timbal $(\mathrm{Pb})$, tembaga $(\mathrm{Cu})$ dan kadmium $(\mathrm{Cd})$ di kawasan Pelabuhan Teluk Bayur Kota Padang. Penelitian ini bertujuan untuk menentukan konsentrasi logam $\mathrm{Pb}, \mathrm{Cu}$ dan $\mathrm{Cd}$ yang terkandung pada air laut di kawasan pelabuhan Teluk Bayur Kota Padang. Alat yang digunakan adalah Atomic Absorbtion Spectroscopy (AAS). Dari pengukuran diperoleh nilai konsentrasi rata-rata untuk $\mathrm{Pb}$ sebesar 0,224 $\mathrm{mg} / \mathrm{L}, \mathrm{Cd}$ tertinggi sebesar 0,005 mg/L dan $\mathrm{Cu}$ paling tinggi adalah 0,964 mg/L. Nilai konsentrasi logam berat pada penelitian ini telah melebihi batas ambang baku mutu Peraturan Menteri Lingkungan Hidup Nomor 51 Tahun 2004. Dari hasil penelitian dapat disimpulkan bahwa kawasan di sekitar pelabuhan Teluk Bayur, Padang telah terkontaminasi logam berat. Kata kunci: Pelabuhan Teluk Bayur, Baku mutu, Atomic absorbtion spectroscopy.
\end{abstract}

\section{ABSTRACT}

Research has been conducted on the identification of lead $(\mathrm{Pb})$, copper $(\mathrm{Cu})$ and cadmium $(\mathrm{Cd})$ heavy metal pollution in the Bay Bayur Port area of Padang City. This study aims to determine the concentration of $\mathrm{Pb}, \mathrm{Cu}$ and $\mathrm{Cd}$ contained in seawater in the Bay Bayur port area of Padang City. The tool used is the Atomic Absorption Spectroscopy (AAS). From the measurements obtained the average concentration value for Pb is $0.224 \mathrm{mg} / \mathrm{L}$, the highest $\mathrm{Cd}$ is $0.005 \mathrm{mg} / \mathrm{L}$ and the highest $\mathrm{Cu}$ is $0.964 \mathrm{mg} / \mathrm{L}$. The concentration of heavy metals in this study has exceeded the quality standard threshold of Minister of Environment Regulation No. 51 of 2004. From the results of the study it can be concluded that the area around the Teluk Bayur port, Padang has been contaminated with heavy metals.

Keywords: Teluk Bayur port, quality standard, Atomic Absorption Spectroscopy. 


\section{PENDAHULUAN}

Air laut mempunyai kemampuan yang besar untuk melarutkan bermacam-macam zat, baik yang berupa gas, cairan maupun padatan. Salah satu zat terlarut yang terkandung di dalam air laut adalah logam berat (Hutagalung, 1984). Keberadaan kadar logam berat yang terlarut pada air laut, sedimen dan lokan (Geloina Coaxans) sangat memengaruhi baik dan buruknya kondisi air laut. Hal ini disebabkan karena logam berat sukar mengalami pelapukan, baik secara fisika, kimia, maupun biologis. Logam berat yang sering dijumpai dalam perairan adalah timbal $(\mathrm{Pb})$, tembaga $(\mathrm{Cu})$ dan $\operatorname{Kadmium}(\mathrm{Cd})$ (Palar, 2004).

Pencemaran air laut biasanya berasal dari air yang terkontaminasi oleh limbah buangan industri dan aktivitas pelabuhan. Semakin tinggi aktivitas pabrik dan kendaraan di sekitar perairan baik di darat maupun areal pantainya maka kadar logam berat dapat meningkat pula (Anggraini, 2007).

WHO (1992) mengemukakan logam Cd dapat tersebar sejauh $50 \mathrm{~km}$ dari sumbernya saat di dalam air. Penelitian yang dilakukan di perairan bagian barat Teluk Jakarta memeroleh hasil bahwa kandungan $\mathrm{Cd}$ sebesar $0,47 \mathrm{mg} / \mathrm{l}$, hasil tersebut sudah melebihi baku mutu air laut menurut KepMen LH No 51 tahun 2004 yaitu 0,002 mg/l (Rohyatun \& Rizak, 2007).

Arifin (2012) melakukan penelitian mengenai kandungan logam berat air laut di Pelabuhan Bungus Kota Padang. Daerah pengambilan sampel di sekitar Pelabuhan Perikanan Samudera, pantai Carolin, Depot Pertamina, Teluk Pandan, UPTD (Unit Pelaksanaan Teknik Dinas) BBIP (Balai Benih Ikan Pantai) Teluk Buo dan di laut lepas dengan hasil penelitian menunjukkan kandungan logam $\mathrm{Cd}$ antara $(0,006-0,01) \mathrm{ppm}, \mathrm{Cu}$ antara $(0,0058-0,0720) \mathrm{ppm}, \mathrm{Cr}$ antara $(0,0170-0,0890) \mathrm{ppm}$ dan kandungan logam $\mathrm{Pb}$ berkisar antara $(0,06-0,09)$ ppm. Berdasarkan Keputusan Menteri Negara Lingkungan Hidup No. 51 Tahun 2004 kandungan logam $\mathrm{Cr}$ dan $\mathrm{Pb}$ telah melampaui standar baku mutu air laut yaitu 0,001 ppm (part per million), sedangkan kandungan logam $\mathrm{Cd}$ dan $\mathrm{Cu}$ belum melampaui standar baku mutu air laut.

Penelitian ini dilakukan untuk mengidentifikasi logam berat yang terdapat dikawasan sekitar pelabuhan Teluk Bayur Kota Padang. Penelitian ini perlu dilakukan karena aktifitas pelabuhan, kendaraan dan limbah rumah tangga yang dibuang ke perairan laut berpotensi mencemari air laut. Untuk mengetahui kadar logam berat pada sampel air laut maka pada penelitian ini digunakan alat Atomic Absorbtion Spectroscopy (AAS).

\section{METODE}

Penelitian ini dilakukan pada bulan Agustus 2018 sampai dengan Desember 2018 yang bertempat di Laboratorium Fisika Material Jurusan Fisika, FMIPA Universitas Andalas dan Laboratorium Kopertis Wilayah X Padang. Alat yang dilakukan antara lain Global Positioning System (GPS), hotplate, Atomic Arbsorption Spectroscopy (AAS).

\subsection{Pengambilan Sampel}

Sampel yang digunakan pada penelitian ini adalah air laut di sekitar Teluk Bayur Kota Padang. Sampel diambil pada lima stasiun dengan jarak antara stasiun adalah 500 meter. Posisi titik sampel yang diambil disesuaikan dengan konsentrasi kegiatan yang diidentifikasikan sebagai sumber dampak kualitas air. Pada setiap stasiun diambil tiga titik sampel, dua sampel di tepi pantai dan satu sampel di laut sekitar 200 meter dari tepi 
pantai. Sampel diambil pada lima stasiun yang berjumlah 15 titik, dengan masing-masing titik sebanyak $500 \mathrm{~mL}$. Kemudian sampel tersebut dimasukkan ke dalam botol plastik dan selanjutnya dibawa ke laboratorium untuk dilakukan pengukuran. Lokasi titik-titik stasiun pengambilan sampel diperlihatkan pada Gambar 1.

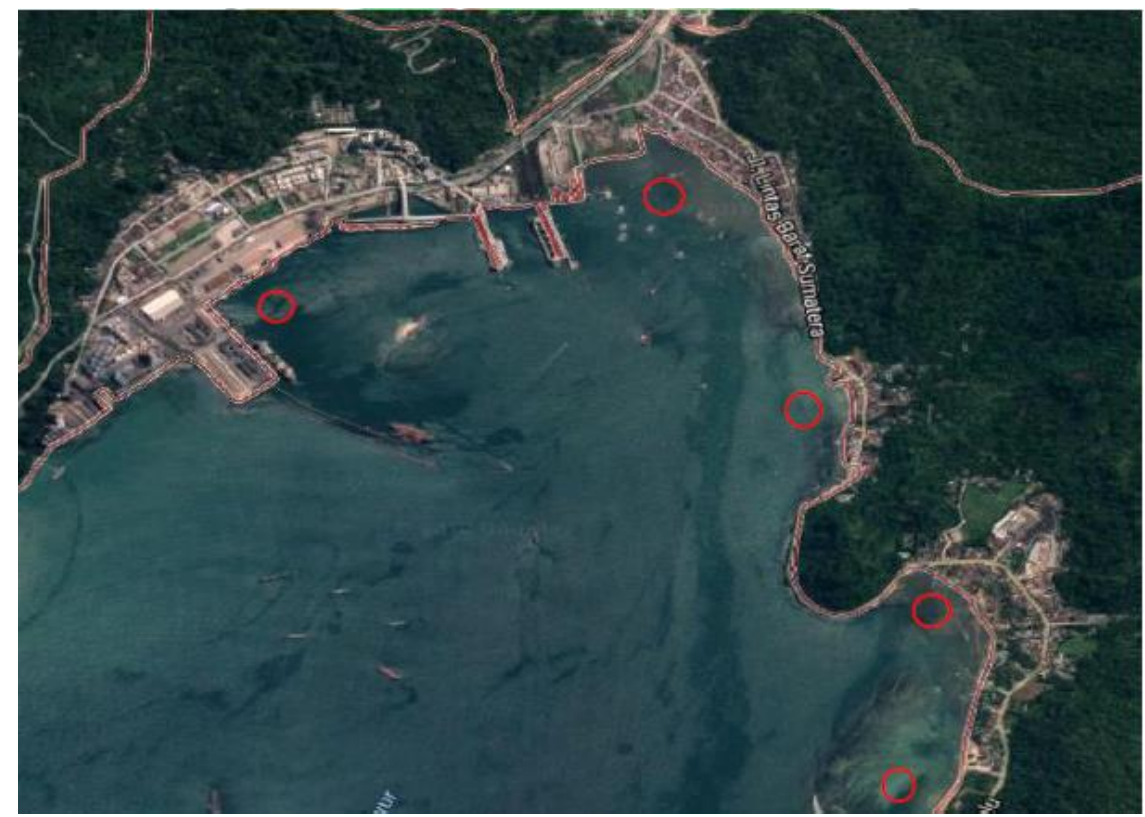

Gambar 1. Lokasi titik-titik pengambilan sampel di perairan sekitar Pelabuhan Teluk Bayur, Padang, Sumatera Barat

\subsection{Pengujian Sampel}

Pengukuran kandungan logam dalam sampel air laut dengan menggunakan Atomic Arbsoption Spectroscopy (AAS) dilakukan melalui langkah-langkah sebagai berikut: (1) Sampel diambil sebanyak $25 \mathrm{ml}$ menggunakan pipet tetes dan kemudian sampel dimasukkan ke dalam beaker glass $50 \mathrm{ml}$, lalu sampel ditambahkan larutan $\mathrm{HNO}_{3}$ sebanyak 2,5 ml. (2) Setelah itu sampel yang sudah dicampur dengan larutan $\mathrm{HNO}_{3}$ diletakkan di atas hotplate hingga volume sampel menjadi 10-15 ml, kemudian sampel dipindahkan ke labu ukur $25 \mathrm{ml}$. (3) Selanjutnya beaker glass dibilas menggunakan aquades sebanyak 3 kali, kemudian air hasil bilasan beaker glass tersebut di masukkan ke dalam labu ukur, aquades ditambahkan ke dalam labu ukur hingga sampai tanda batas 25 ml. (4) Langkah terakhir, sampel dipindahkan ke botol plastik (ditutup rapat) sebelum dimasukkan ke dalam Atomic Absorbtion Spectroscopy (AAS) Setelah langkah-langkah tersebut dilakukan, komputer akan membaca kandungan logam berat dan hasil tersebut ditampilkan pada layar komputer.

\subsection{Pengolahan Data}

Data yang diolah adalah data kandungan logam berat dari hasil pengukuran sampel menggunakan alat Atomic Absorbtion Spectroscopy (AAS). Pengolahan data mencakup menghitung nilai rata-rata konsentrasi kandungan logam dari setiap sampel, kemudian hasil tersebut ditampilkan dalam bentuk grafik. 


\subsection{Analisis Data}

Analisis data yang dilakukan adalah dengan menganalisis penyebaran logam berat di perairan Teluk Bayur pada 15 titik sampel yang telah dilakukan, kemudian dihitung nilai rata-ratanya untuk tiap stasiun. Hasil tersebut ditampilkan dalam bentuk grafik dan dibandingkan dengan standar baku mutu Keputusan Menteri Negara Lingkungan Hidup No. 51 Tahun 2004 dan No 82 Tahun 2001.

\section{HASIL DAN DISKUSI}

\subsection{Hasil Pengujian Logam Berat}

Hasil pengukuran kandungan logam berat dari 15 titik sampel air laut di perairan pelabuhan Teluk Bayur kota Padang diberikan pada Tabel 1. Dari hasil pengujian yang diperoleh dapat dilihat bahwa sebagian besar lokasi titik-titik sampel mengandung logam berat, selain itu juga terdapat lokasi yang tidak terdeteksi logam berat.

Tabel 1. Hasil pengujian kandungan logam berat $\mathrm{Pb}, \mathrm{Cu}$ dan $\mathrm{Cd}$.

\begin{tabular}{|c|c|c|c|c|}
\hline \multirow{2}{*}{ Stasiun } & \multirow{2}{*}{ Sampel } & \multicolumn{3}{|c|}{ Konsentrasi (mg/L) } \\
\hline & & $\mathbf{P b}$ & Cd & $\mathbf{C u}$ \\
\hline \multirow{3}{*}{1} & 1.1.M & 0 & 0,006 & 0,028 \\
\hline & 1.T.1 & 0,191 & 0,005 & 0,072 \\
\hline & 1.T.2 & 0,331 & 0,005 & 0,072 \\
\hline \multirow{3}{*}{2} & 2.1.M & 0 & 0,003 & 0,234 \\
\hline & 2.T.1 & 0 & 0,004 & 0,226 \\
\hline & 2.T.2 & 0,353 & 0,004 & 0,045 \\
\hline \multirow{3}{*}{3} & 3.1.M & 0,019 & 0,004 & 0,075 \\
\hline & 3.T.1 & 0,226 & 0,005 & 0,137 \\
\hline & 3.T.2 & 0,033 & 0,005 & 0,964 \\
\hline \multirow{3}{*}{4} & 4.1.M & 0,174 & 0,004 & 0,030 \\
\hline & 4.T.1 & 0,84 & 0,004 & 0,035 \\
\hline & 4.T.2 & 0,070 & 0,006 & 0,032 \\
\hline \multirow{3}{*}{5} & 5.1.M & 0 & 0,001 & 0,026 \\
\hline & 5.T.1 & 0 & 0,001 & 0,029 \\
\hline & 5.T.2 & 0,009 & 0,002 & 0,048 \\
\hline \multirow{2}{*}{\multicolumn{2}{|c|}{$\begin{array}{l}\text { Konsentrasi rata-rata } \\
\text { Nilai Tertinggi }\end{array}$}} & 0,224 & 0,004 & $\mathbf{0 , 1 3 7}$ \\
\hline & & 0,840 & $\mathbf{0 , 0 0 6}$ & $\mathbf{0 , 9 6 4}$ \\
\hline
\end{tabular}

\subsection{Analisis Logam Berat $\mathbf{P b}$}

Berdasarkan nilai kandungan logam $\mathrm{Pb}$ pada 15 sampel air laut di kawasan Pelabuhan Teluk Bayur Kota Padang, maka didapatkan konsentrasi rata-rata logam $\mathrm{Pb}$ untuk setiap stasiun. Gambar 2 merupakan grafik nilai konsentrasi rata-rata logam $\mathrm{Pb}$ pada stasiun 1 sampai 5 . 


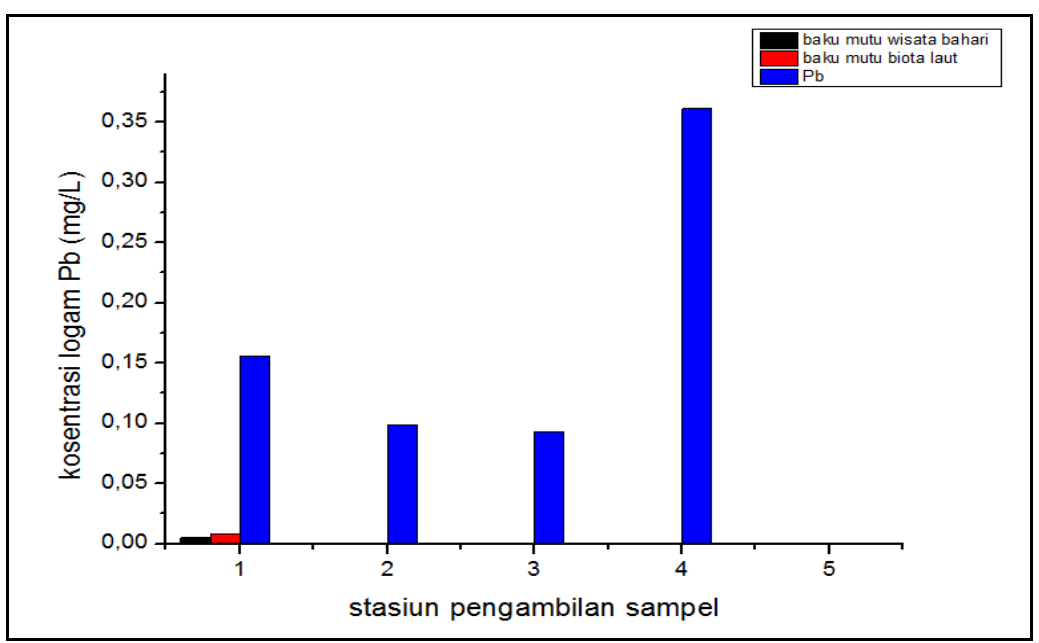

Gambar 2. Grafik nilai konsentrasi $\mathrm{Pb}$ dengan perbandingan baku mutu air laut untuk wisata bahari dan biota laut terhadap stasiun pengambilan sampel.

Pada Gambar 2 dapat dilihat konsentrasi logam $\mathrm{Pb}$ pada air laut telah melampaui baku mutu yang telah ditetapkan pemerintah, berdasarkan keputusan Menteri Lingkungan Hidup Nomor 51 Tahun 2004. Konsentrasi logam Pb tersebut telah melampaui baku mutu untuk wisata bahari maupun biota laut. Dari 5 stasiun pengambilan sampel, 4 stasiun melampaui batas baku mutu yang telah ditetapkan oleh pemerintah. Tingginya kandungan logam $\mathrm{Pb}$ di 4 stasiun yang melampaui baku mutu disebabkan lokasi stasiun yang dekat dengan jalan raya dengan kegiatan transportasi yang cukup padat sehingga menghasilkan emisi yang mencemari perairan. Senyawa $\mathrm{Pb}$ yang terdapat pada emisi kegiatan trasportasi dan industri dapat masuk ke perairan melalui pengkristalan di udara dan jatuh melalui air hujan (Palar, 1994). Hasil ini sama seperti yang didapatkan oleh Walukow dkk., (2008) yang melaporkan bahwa kandungan logam $\mathrm{Pb}$ pada air Sungai Cikaniki diduga berasal dari tingginya aktifitas transportasi yang menghasilkan emisi di kawasan tersebut. Agustina dkk., (2012) juga melaporkan hal yang sama bahwa tingginya beban pencemar logam $\mathrm{Pb}$ pada air Sungai Siak kemungkinan berasal dari udara melalui hasil pembakaran bahan bakar fosil.

\subsection{Analisis Logam Berat Cd}

Gambar 3 memperlihatkan grafik nilai konsentrasi Cd dengan perbandingan baku mutu air laut untuk wisata bahari dan biota laut terhadap stasiun pengambilan sampel. Dari grafik dapat dilihat kandungan logam $\mathrm{Cd}$ di kawasan pelabuhan Teluk Bayur Kota Padang sudah melampaui baku mutu yang telah ditetapkan. Berdasarkan keputusan Menteri Lingkungan Hidup Nomor 51 Tahun 2004, nilai baku mutu air laut untuk biota laut adalah $0,001 \mathrm{mg} / \mathrm{L}$ dan wisata bahari adalah $0,002 \mathrm{mg} / \mathrm{L}$.

Kandungan logam berat Cd yang melebihi baku mutu air laut ini disebabkan kegiatan yang terdapat di sekitar pelabuhan seperti kegiatan rumah tangga dan industri. Masyarakat di sekitar pelabuhan yang pada umumnya membuang limbah domestik ke laut menyebabkan tingginya kandungan $\mathrm{Cd}$ di perairan pelabuhan Teluk Bayur. Hasil yang cenderung sama juga diperoleh oleh Sugianto dan Fretty (2017), yang melaporkan bahwa kandungan logam berat $\mathrm{Cd}$ yang terdapat pada sungai Siak khususnya daerah Perawang disebabkan pencemaran limbah domestik masyarakat. Indirawati (2017) menyatakan bahwa kandungan $\mathrm{Cd}$ dalam air laut dan sungai berasal dari pencemaran limbah domestik dan industri. 


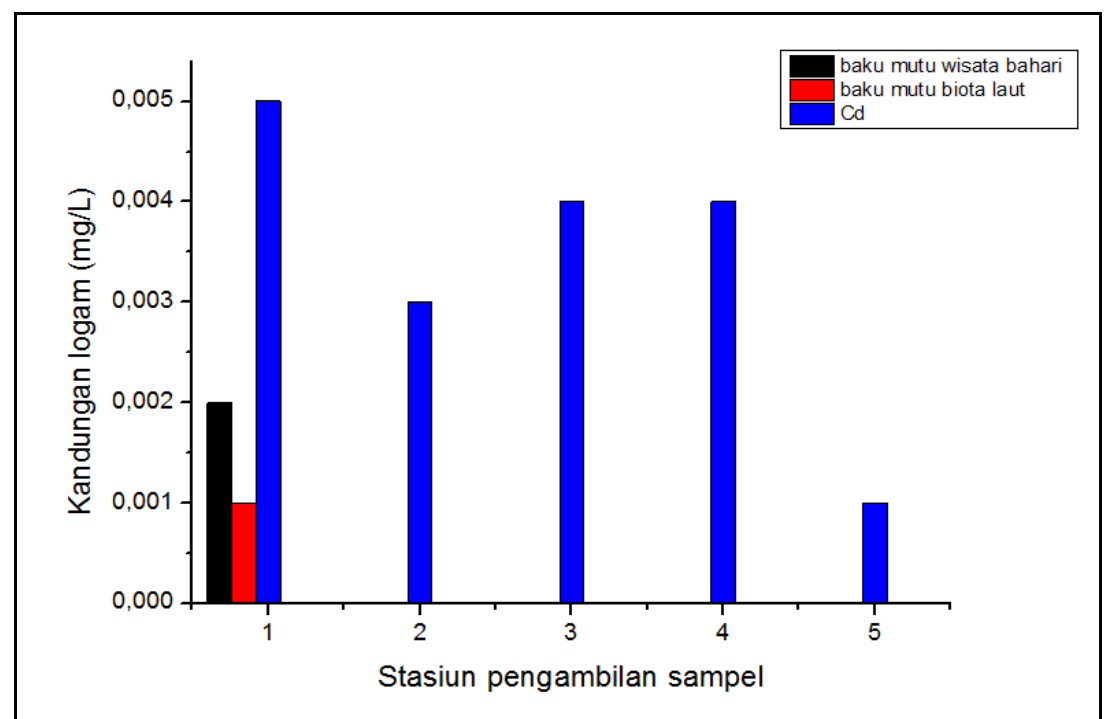

Gambar 3. Grafik nilai konsentrasi Cd dengan perbandingan baku mutu air laut untuk wisata bahari dan biota laut terhadap stasiun pengambilan sampel

\subsection{Analisis Logam Berat Cu}

Gambar 4 menunjukkan grafik nilai kandungan rata-rata pencemaran logam berat pada setiap stasiun. Dari grafik dapat dilihat tingkat pencemaran logam berat $\mathrm{Cu}$ tertinggi terdapat pada stasiun 3. Padatnya pemukiman penduduk di sekitar stasiun 3 menyebabkan tingginya tingkat pencemaran logam berat $\mathrm{Cu}$ di sekitar Pelabuhan Teluk Bayur. Hal ini disebabkan masyarakat yang membuang limbah domestik di perairan Teluk Bayur. Pencemaran logam berat $\mathrm{Cu}$ diakibatkan oleh aliran limbah rumah tangga yang mengalir ke laut dan adanya aktifitas industri pengolahan kayu yang juga membuang limbahnya di sekitar perairan Teluk Bayur. Palar (1994) menyatakan bahwa limbah logam berat yang berasal dari industri pengolahan kayu disebabkan penggunaa logam $\mathrm{Cu}$ sebagai campuran bahan pengawet.

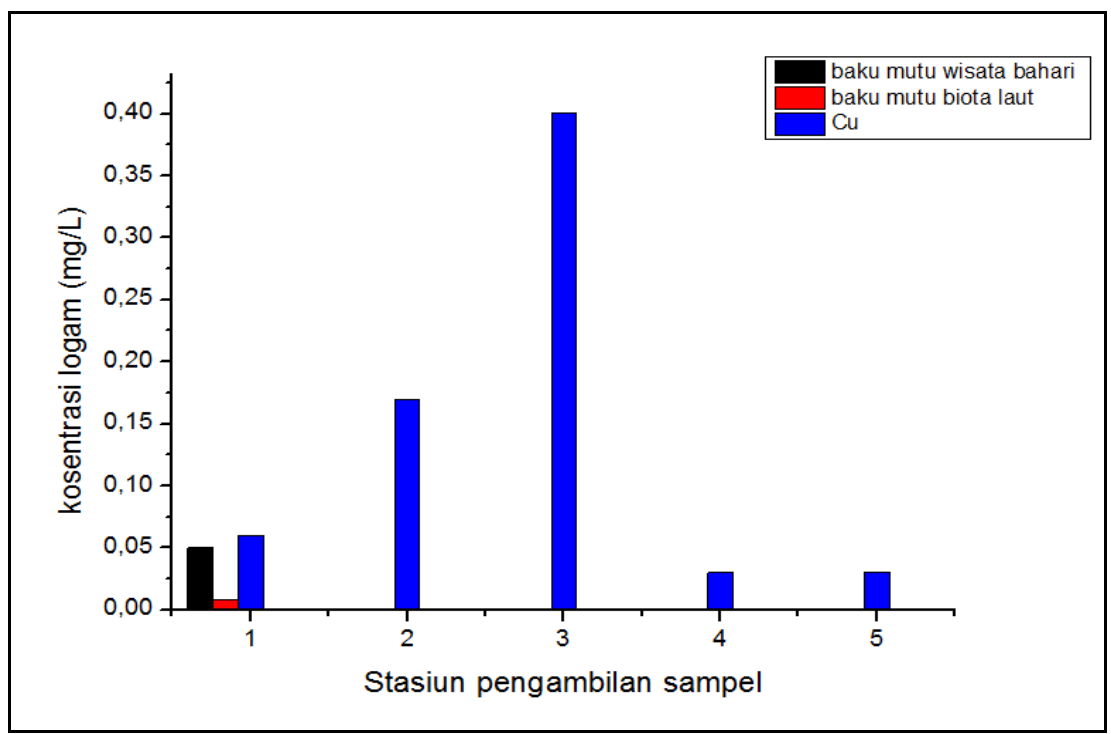

Gambar 4. Grafik nilai konsentrasi Cu dengan perbandingan baku mutu air laut untuk wisata bahari dan biota laut terhadap stasiun pengambilan sampel. 
Menurut Keputusan Menteri Lingkungan Hidup Nomor 51 Tahun 2004, nilai baku mutu logam berat $\mathrm{Cu}$ pada air laut untuk wisata bahari adalah $0,050 \mathrm{mg} / \mathrm{L}$ dan biota laut adalah $0,008 \mathrm{mg} / \mathrm{L}$. Berdasarkan hasil pengujian logam berat $\mathrm{Cu}$ dapat disimpulkan bahwa kawasan di sekitar Pelabuhan Teluk Bayur Kota Padang tercemar oleh logam berat $\mathrm{Cu}$.

\section{KESIMPULAN}

Dari hasil penelitian dapat disimpulkan bahwa kawasan di sekitar pelabuhan Teluk Bayur Padang telah terkontaminasi logam berat berdasarkan Keputusan Menteri Lingkungan Hidup No 51 Tahun 2004 tentang Baku Mutu Air laut.

\section{UCAPAN TERIMA KASIH}

Penulis mengucapkan terimakasih kepada Program Kreativitas Mahasiswa Universitas Andalas 2019 atas pendanaan penelitian ini.

\section{DAFTAR PUSTAKA}

Agustina, Y., Amin, B., \& Thamrin. (2012). Analisis beban dan indeks pencemar ditinjau dari parameter logam berat di Sungai Siak Kota Pekanbaru. Jurnal Ilmu Lingkungan, ISSN 1978-5283, 162-172.

Anggraini, D. (2007). Analisis kadar logam berat Pb, Cd, Cu dan Zn pada air laut, sedimen dan lokan (Geloina Coaxans) di perairan Pesisir Dumai, Provinsi Riau (Skripsi). Universitas Riau, Fakultas Perikanan, Pekanbaru, Indonesia.

Arifin B. (2012). Analisis kandungan logam $\mathrm{Cd}, \mathrm{Cu}, \mathrm{Cr}$ dan $\mathrm{Pb}$ dalam air laut di sekitar Perairan Bungus Teluk Kabung Kota Padang. Jurnal Dampak, 9, 116-122.

Effendi. (2003). Telaah kualitas air pengelolaan sumber daya dan lingkungan perairan. Yogyakarta: Kanisius.

Hutagalung, H. P. (1984). Logam berat dalam lingkungan laut. Jurnal Oseana, IX, 1120.

Indirawati S. M. (2017). Pencemaran logam berat $\mathrm{Pb}$ dan $\mathrm{Cd}$ dan keluhan kesehatan pada masyarakat di kawasan Pesisir Belawan. Jurnal JUMANTIK, 2, 54-60.

Palar, H. (1994). Pencemaran dan toksikologi logam berat. Jakarta: Rineka Cipta.

Rohyatun, E. \& Rizak, A. (2007). Pemantauan pada logam berat dalam sedimen di perairan Teluk Jakarta. Jurnal Makara Sains, 11, 28-36, 968-975.

Sugianto dan Fretty, S. R. M. (2017). Analisis logam berat Fe, Cd, dan Cu pada limbah industri. Jurnal Komunikasi Fisika Indonesia, Edisi April ISSN.1412-2960.

Walukow, A. F., Djokosetiyanto, D., Kholil, Soedharma, D. (2008). Analisis beban pencemaran dan kapasitas asimilasi Danau Sentani, Papua sebagai upaya konservasi lingkungan perairan. Jurnal Berita Biologi, 9 (3), 229-236.

World Health Organization. (1992). The ICD-10 classification of mental and behavioural disorders: clinical descriptions and diagnostic guidelines. Geneva, Swiss: Author. 